\title{
IFRS Convergence and Disclosure Quality: The Role of Audit Quality Moderation (Study on Multinational Companies in Indonesia)
}

\author{
Fatmasari Sukesti ${ }^{1, *}$, Abdul Kharis Almasyhari ${ }^{1}$, Nurul Nazlia Jamil ${ }^{2}$, Ainulashikin Marzuki ${ }^{2}$ \\ ${ }^{1}$ Department of Accounting, Faculty of Economics, Universitas Muhammadiyah Semarang, Indonesia \\ ${ }^{2}$ Faculty of Economics and Muamalat, Universiti Sains Islam Malaysia, Malaysia
}

Received September 23, 2021; Revised November 24, 2021; Accepted December 13, 2021

\begin{abstract}
Cite This Paper in the following Citation Styles
(a): [1] Fatmasari Sukesti, Abdul Kharis Almasyhari, Nurul Nazlia Jamil, Ainulashikin Marzuki , "IFRS Convergence and Disclosure Quality: The Role of Audit Quality Moderation (Study on Multinational Companies in Indonesia)," Universal Journal of Accounting and Finance, Vol. 10, No. 1, pp. 72-81, 2022. DOI: 10.13189/ujaf.2022.100108.
\end{abstract}

(b): Fatmasari Sukesti, Abdul Kharis Almasyhari, Nurul Nazlia Jamil, Ainulashikin Marzuki (2022). IFRS Convergence and Disclosure Quality: The Role of Audit Quality Moderation (Study on Multinational Companies in Indonesia). Universal Journal of Accounting and Finance, 10(1), 72-81. DOI: 10.13189/ujaf.2022.100108.

Copyright $\bigcirc 2022$ by authors, all rights reserved. Authors agree that this article remains permanently open access under the terms of the Creative Commons Attribution License 4.0 International License

\begin{abstract}
IFRS convergence was initiated through the agreement of the G20 leadership meeting in Washington at 2008. The meeting agreed to use IFRS as an international accounting standard. Adopting IFRS as a single global accounting standard can make Indonesian companies ready and able to transact across countries, or mergers and acquisitions. IFRS supports the readiness of industry in Indonesia to be competitive at the global level. Financial statements based on IFRS produce information more relevant, accurate and more comparable. IFRS can produce valid information on company assets, liabilities, equity, income and expenses. Management will have a high level of accountability to run the company. This study examined the role of audit quality as moderating variable in the relationship between the IFRS convergence and disclosure quality, and studies on multinational companies listed the Indonesian Stock Exchange 2012-2018 period. The research used 63 multinational companies and it tested using the SPSS 25 statistical test tool. The research has proven the effect of IFRS convergence on disclosure quality, and the role of audit quality in strengthening the relationship between the two variables. IFRS convergence applied requires the role of external audit to provide assurance or assurance that the financial statements presented have complied with the standards for preparing financial statements and are fairly presented without material errors.
\end{abstract}

Keywords IFRS Convergence, Disclosure Quality, Audit Quality

\section{Introduction}

International Financial Reporting Standard (IFRS) has been accepted as a global accounting standard in order to provide quality financial information on international capital markets. IFRS has been adopted by many countries including the European Union countries, which have used IFRS since 2005 [1]. Canada and several countries in Asia Pacific have converged from their domestic accounting with IFRS. Australia and New Zealand have adopted IFRS since 2005, and the United States replaced the accounting standards to IFRS. Hong Kong, the Philippines and Singapore have adopted IFRS. Since 2008, 80 countries have required companies that have been listed on global stock exchanges to apply IFRS in preparing and presenting their financial reports [1]. The obligation to use IFRS for listed companies is one of the most significant changes in the history of accounting regulations [2].

IFRS convergence in Indonesia intended to combine or integrate local financial accounting standards to direct to IFRS. Indonesia did not use IFRS full adoption. The IFRS convergence process has been carried out in stages 
starting in 2008 with a target completion in 2012. Then the next phase is the implementation phase in 2012-2015. So there is a difference in the effective date between the applications of local financial accounting standards to IFRS convergence.

IFRS convergence in Indonesia is carried out by three stages. The first stage is adoption IFRS stage which progresses from 2008-2010. The end of 2010 is expected that all IFRS have been adopted on financial accounting standards local. Second stage is the final preparation stage for the completion of supporting infrastructure, which has been done in 2011 to support the implementation of local standards which has adopted all IFRS. And the third phase is the implementation which took place in 2012, where financial accounting standards local based on IFRS must be applied by companies that have public accountability.

The adoption of international accounting standards into domestic accounting standards aims to produce financial reports that have a high level of credibility, and the requirements for item disclosure will be higher so that the company value will be even higher. Petreski [3] stated that financial statements based on IFRS produce information that is more relevant, accurate and more comparable, producing valid information on company assets, liabilities, equity, income and expenses. Management will have a high level of accountability to running the company. Indonesia launched an international accounting standard in 2008. The government, through Bapepam-Lembaga Keuangan and the Ministry of Finance strongly supports the domestic accounting standards convert to IFRS convergence program because it is considered in line with one of the agreements of the leaders of countries that are members of the G20, to implementing a set of standards quality accounting that applies internationally.

The results of previous studies examining the effect of IFRS on the quality of disclosure proved that IFRS adoption in various countries has a role in improving the quality of disclosure. Blouin et al [4] showed that there was a difference in the increase in company report disclosure after IFRS adoption on 100 companies between 2005-2006. Blouin's research supported by the findings of [5] which proved that the implementation of FIN 48 has a significant effect on increasing the type and amount of information provided in financial reports about tax uncertainty and the amount of multinational company taxes. The information caused transactions in the financial statements to be more transparent and better understood by external parties.

Mardini et al [6] tested 109 companies in Jordan using the disclosure index checklist to assess the effect of IFRS adoption, he found that the total application of IFRS on disclosure items increases compared to the period before the implementation of IFRS. The increase in the quality of disclosure before IFRS adoption was $76.8 \%$, it was increasing to $87 \%$ after IFRS adoption. In general, the adoption of IFRS improves the quality of information presented in financial statements by increasing disclosure quality $[7,8]$.

However, several studies proved that the effect of IFRS adoption on financial disclosure is different in each country. Differences in disclosure in financial statements are influenced by cultural factors in countries that adopt IFRS. The information disclosed in a company's financial statements is a function of its environment, where culture is an important factor. Hope [9] found that cultural dimensions affect the level of corporate financial disclosure in various countries. Akman [10] also showed that culture still plays a role in the level of corporate financial disclosure even after IFRS adoption, even though the level of disclosure increases in all countries examined after IFRS adoption. The results showed that the use of the same accounting standards does not completely eliminate differences in disclosure and companies continue to disclose information according to their cultural backgrounds.

Financial statements disclosure will help users to better understand the condition of the company financial statements reported. Failure understanding of an information can lead to errors in judgment. This condition will cause an information gap between management and users of financial reports. Adhariani [11] showed the level of voluntary disclosure for manufacturing companies and the public sector was only around $14.6 \%$ - $43.65 \%$. Adhariani's research supports research conducted by Pricewaterhouse Coopers which stated that Indonesia ranks very low in terms of perceptions of accountability standards, implementation of auditing and compliance, as well as disclosure and transparency.

The results of previous studies found that there were inconsistencies in the relationship between IFRS and disclosure quality, and the low level of disclosure, as well as the IFRS convergence process that took place gradually, there made interesting reasons for research on companies in Indonesia. There is suspect have factors can strengthen or weakness the relationship between the influences of IFRS implementation on the quality of financial reporting disclosures.

Agency theory explained the cause of agency conflict is the existence of information asymmetry between the principal and the agent. The information asymmetry can be reduced by the oversight role of the external auditor. Through a monitoring mechanism called an audit, it can play an important role in monitoring contracts and reducing information risk. Wallace \& Kreutzfeldt [12] stated that auditing is a way can reduce agency costs due to selfish behavior by managers and information asymmetry. On the basis of these considerations, this study adds the Audit Quality variable as a moderating variable which is expected to strengthen the effect of IFRS on Disclosure Quality. An audit conducted by an external auditor provides assurance that the financial statements are fairly presented without material errors. 
External auditors are seen as representatives of stakeholders to assess the truth of the accounting reports made by the company's management.

Marra et al [13] said the convergence of IFRS with a more comprehensive level of audit complexity required a reliable auditor to make adequate estimates and relevant professional judgments. Good audit quality will strengthen the position of financial statements while carrying out monitoring functions as part of the company's good corporate governance $[14,15]$.

Moderating variable is expected to strengthen the relationship between the effects of IFRS convergence on increasing corporate disclosure. Using the concept of agency theory which said that management cannot be trusted and supervision is needed; the management can be controlled by using audit as a monitoring function to reduce agency costs. Mutmainnah \& Wardhani [16], Istiqomah \& Adhariani [17] and Sari \& Indarto [18] proved audit quality can play a role as a moderating variable that strengthens or weakens the relationship between variables.

\section{Literature Review}

Agency theory [19] explains the difference in interests between principals and management. The more complicated the firm, the owners cannot intensively manage the company, and they delegate to the management. This condition causes information asymmetry between the principal and the agent. Information asymmetry causes agency conflict.

Disclosure presented in financial statements is one of the important media to resolve agency conflicts. The existence of information disclosure by management can provide an overview of the company's condition to shareholders, so that it can anticipate the occurrence of deviations of interest that will be carried out by managers. Adequate disclosure of information by management can reduce agency costs that occur, in addition, quality disclosure shows the credibility of the company and can help users to understand the strategy and various other information about the company needed.

Mardini et al [6] showed that the implementation of IFRS can increase the amount of business information. Increasing the quantity and quality of information improves the quality of financial reports where the information will be very useful for decision making [7]. The quantity and quality of the information disclosed in the financial statements is expected to reduce the level of information asymmetry between management and investors. Lobo et al [20] also stated that the quality of disclosure has a negative relationship with earnings management.

Borkowski \& Gaffney [5] found a relationship between the quality and quantity of disclosure on tax disclosures and financial reporting in countries was adopted IFRS. Disclosure quality provides tax transaction information on multinational companies that is more transparent and understandable for users of the company's external financial [6] statements. The statement is supported by and [7] which stated that the adoption of IFRS affects the quality of disclosure and the quality of this disclosure affects the improvement of the quality of information in financial statements. Pour \& Arabi [21] stated the more information is disclosed, the less information asymmetry between principals and managers.

The effect of IFRS application on disclosure quality has been shown to increase from $76.80 \%$ before the IFRS adoption period to $87.09 \%$ after the IFRS adoption period in companies listed on the Ghana Stock Exchange [7]. Blouin et al and Borkowski et al [4,5] support the research and stated that the adoption of IFRS improves the quality and quantity of disclosure of completeness of disclosure on transfer pricing activities in multinational companies which makes transactions between companies more transparent and easier to understand by external users. The results are supported by previous research by [22], which predicts future company performance, which means that disclosure quality is influenced by IFRS adoption and helps users interpret financial statements better. Based on the results of previous research, the research hypothesis is stated as follows:

\section{H1: IFRS convergence has a positive effect on Disclosure Quality}

Auditors have an attest function that provides credibility to the financial statements. The attest function is an important position to maintain the quality of earnings and protect the welfare of shareholders. The role of independent auditors has been emphasized by Sarbanes Oxley (SOX) through the Public Company Accounting Oversight Board (PCAOB) which regulates their work. In order to maintain auditor independence, the regulation has established responsibility for dealing with auditors, which are expected to avoid earnings management to protect the auditor's reputation and avoid expensive litigation [23].

External audit is used as monitoring function in companies. Agency theory showed that external audit can reduce the asymmetry information presented by management. Auditing will strengthen the position of financial statements in complying with financial statement presentation standards. Mutmainnah \&Wardhani [16] used audit quality as a moderating variable in the relationship between the influence of the audit committee on the quality of financial reports that found evidence that Accountant Public Firm size has a significant effect on strengthening the relationship between audit committees and earnings persistence.

Based on the above research, this study used audit quality as a moderating variable to strengthen the positive relationship between IFRS convergence and disclosure 
quality, so the following hypothesis is stated:

H2: Audit Quality strengthens the positive relationship between IFRS convergence and Disclosure Quality

\section{Material and Methods}

\subsection{Sample and Data}

The sample is multinational companies listed on the stock exchange in Indonesia. The assumption used that IFRS implementation for financial statements of public companies in multinational companies more required than domestic companies. The multinational financial statements companies will be compared with companies around the world that have adopted IFRS.

This study used secondary data from the annual reports of multinational companies listed on the Indonesia Stock Exchange 2012-2018 period and sample of 63 multinational companies.

\subsection{Definition and Variable Measurement}

\section{IFRS convergence}

Referring to [24] which adopted by [25] with several modifications and adjustments to the application of IFRS in Indonesia.
The ratio of IFRS-based accounting standards applied by companies to the number of accounting standards issued by relevant professions for multinational companies

\section{Disclosure Quality}

Disclosure has the meaning of not covering or hiding. Disclosure in financial statements means providing useful data that is informative for decision makers. The completeness of the information that must be disclosed in the financial statements depends on the expertise of the readers, as well as the standards set by the regulator. The level of disclosure of company information is measured using an unweighted disclosure index.

The list of mandatory and voluntary disclosure items is based on the list of items that have been carried out by previous researchers $[25,26]$ with reference to the disclosure quality dimension of the IASB used by [7]. The checklist or list of items in this study has been adjusted to the Decree of the Chairman of the Capital Market and Financial Institution Supervisory Agency Number: KEP-347/BL/2012 concerning Presentation and Disclosure of Financial Statements of Issuers or Public Companies. Disclosure check list is presented in table 1.

Table 1. Disclosure Quality Checklist

\begin{tabular}{|c|c|c|}
\hline \multicolumn{3}{|c|}{ Comprehensive disclosure checklist } \\
\hline No & Disclosure Checklist & Maximum score \\
\hline \multicolumn{2}{|r|}{ General Corporate Information } & 17 \\
\hline $\begin{array}{l}1 \\
2 \\
3 \\
4 \\
5 \\
6 \\
7 \\
8 \\
9 \\
10 \\
11 \\
12 \\
13 \\
14 \\
15 \\
16 \\
17\end{array}$ & $\begin{array}{c}\text { Company name and address } \\
\text { Brief history of company } \\
\text { Products and or services } \\
\text { Organization structure } \\
\text { Vision and mission } \\
\text { Name, position and profile the board of directors } \\
\text { Name, position and profile of directors } \\
\text { Number of employees } \\
\text { Shareholder composition } \\
\text { Composition of subsidiaries } \\
\text { Stock listing chronology } \\
\text { Operational information } \\
\text { Financial overview } \\
\text { Stock overview } \\
\text { Stock price and trading volume } \\
\text { Corporate strategy and firm values } \\
\text { Awards and certifications }\end{array}$ & \\
\hline \multicolumn{2}{|r|}{ Management Report } & 8 \\
\hline $\begin{array}{l}18 \\
19 \\
20 \\
21 \\
22 \\
23 \\
24 \\
25\end{array}$ & $\begin{array}{l}\text { Board of commissioners report } \\
\text { Composition the board of commissioners } \\
\text { The duties and functions the board of commissioners } \\
\text { The composition changes the board of commissioners } \\
\text { Directors report } \\
\text { Composition of directors } \\
\text { The duties and functions directors } \\
\text { The composition changes the board of directors }\end{array}$ & \\
\hline
\end{tabular}


Table 1 Continued

\begin{tabular}{|c|c|c|}
\hline \multicolumn{2}{|r|}{ Analysis and Management Discuss } & 17 \\
\hline $\begin{array}{l}26 \\
27 \\
28 \\
29 \\
30 \\
31 \\
32 \\
33 \\
34 \\
35 \\
36 \\
37 \\
38 \\
39 \\
40 \\
41 \\
42\end{array}$ & $\begin{array}{c}\text { Operation review } \\
\text { Sales/revenue } \\
\text { Profitability } \\
\text { Increased production capacity } \\
\text { Financial condition } \\
\text { Capital structure } \\
\text { Business prospect description } \\
\text { Impact of price changes on net sales } \\
\text { Acquisition } \\
\text { Investment } \\
\text { Expansion } \\
\text { Divestment } \\
\text { Debt/capital restructuring } \\
\text { Material information and facts after the accountant's reporting date } \\
\text { Company business prospects } \\
\text { Marketing strategy } \\
\text { Dividend policy }\end{array}$ & \\
\hline \multicolumn{2}{|r|}{ Corporate Governance } & 7 \\
\hline $\begin{array}{l}43 \\
44 \\
45 \\
46 \\
47 \\
48 \\
49\end{array}$ & $\begin{array}{c}\text { General Meeting of Shareholders } \\
\text { Information disclosure } \\
\text { Internal control and audit } \\
\text { Key risk factors and risk management } \\
\text { Appointment of independent auditor } \\
\text { Litigation } \\
\text { Governance principles and recommendations }\end{array}$ & \\
\hline \multicolumn{2}{|r|}{ Corporate Social Responsibility } & 5 \\
\hline $\begin{array}{l}50 \\
51 \\
52 \\
53 \\
54\end{array}$ & $\begin{array}{c}\text { Sustainable development } \\
\text { Occupational Health and Safety } \\
\text { Community development, education and health } \\
\text { Labor information } \\
\text { Environmental conservation } \\
\end{array}$ & \\
\hline \multicolumn{2}{|r|}{ Financial Information } & 12 \\
\hline $\begin{array}{l}55 \\
56 \\
57 \\
58 \\
59 \\
60 \\
61 \\
62 \\
63 \\
64 \\
65 \\
66\end{array}$ & $\begin{array}{c}\text { Audited financial reports } \\
\text { Explanation of the items presented in the financial statements } \\
\text { Accounting principles and policies applied } \\
\text { Comprehensive income statement } \\
\text { Statement of Changes in Equity } \\
\text { Cash flow statement } \\
\text { Presentation of notes on reports systematically } \\
\text { Disclosure of financial statement items } \\
\text { Disclosure of relationships } \\
\text { Disclosure of transactions and balances with related parties } \\
\text { Disclosure of investments in associates } \\
\text { Events after reporting date }\end{array}$ & \\
\hline \multicolumn{2}{|r|}{ Financial Review Information } & 9 \\
\hline $\begin{array}{l}67 \\
68 \\
69 \\
70 \\
71 \\
72 \\
73 \\
74 \\
75\end{array}$ & $\begin{array}{c}\text { Ratio of profit (loss) to total assets } \\
\text { Ratio of profit (loss) to equity } \\
\text { Current ratio } \\
\text { Liability to equity ratio } \\
\text { Ratio of liabilities to total assets } \\
\text { Comparison of financial position for 3-5 years } \\
\text { Market share of the product } \\
\text { Explanation of changes in market share } \\
\text { New product development discussion }\end{array}$ & \\
\hline \multicolumn{2}{|r|}{ Projected Information } & 4 \\
\hline $\begin{array}{l}76 \\
77 \\
78 \\
79\end{array}$ & $\begin{array}{l}\text { Projection of future profits } \\
\text { Projection of future sales } \\
\text { Forecast of cash flows } \\
\text { Planned capital expenditure }\end{array}$ & \\
\hline
\end{tabular}


Table 1 Continued

\begin{tabular}{|l|c|c|}
\hline \multicolumn{2}{|c|}{ Employee Information } & 4 \\
\hline 80 & Category of employees by sex \\
81 & Category of employees by education & \\
82 & Amount spent on training & \\
83 & Number of employees trained & \\
\hline \multicolumn{2}{|c|}{ Graphic Information } & \\
\hline 84 & Graphic presentation of financial information & \\
85 & Graphic presentation of non financial information & 85 \\
\hline \multicolumn{2}{|l|}{ Total score } & \\
\hline
\end{tabular}

\section{Audit Quality}

Audit quality used audit measurements from several audit quality measurements have been tested by [28] called Audit Quality Metric Score (AQMS). Measurements based on AQMS represent a measure of audit quality in the dimensions of competence and independence. Dimensions of competence are measured by indicators of Public Accountant Firm size (Big 4-non Big 4), Public Accountant Firm, Industry Specialization (Spcl) and audit tenure (audit tenure). While the independence dimension is measured by the size of Client Importance (CI).

Public Accountant Firm size (BIG 4) is one indicator of high audit quality that has been tested in previous studies $[28,29]$. High audit quality is measured by using a dummy variable. In Indonesia, companies that use Public Accountant Firm BIG 4 or Public Accountant Firm affiliated with BIG 4 are assigned a number 1 and 0 otherwise.

Previous research from [30,31] said that audit firms with industry specialization have an influence on improving the quality of financial reports. Gul et al [33] gave the category of Public Accountant Firm with industry specialization (Spcl) having high audit quality if it has the largest industry share in a particular industry. $\mathrm{Spcl}$ is given a score of 1 if it has the largest industry share as measured by the ratio of the number of Public Accountant Firm client assets in a particular industry divided by the number of client assets for all Public Accountant Firm in one industry, and is given a score of 0 if other.

Audit tenure is an audit quality used by several researchers [33,34]. Audit tenure measured by the medium term is $>3$ years and $<9$ years is the audit assignment period which is considered sufficient to understand the client and the company but does not reduce independence as audit quality from Public Accountant Firm. Public Accountant Firm assignment period that is in the interval $>3$ years and $<9$ years is proxied as high audit quality and is given a number 1 , and 0 otherwise.

Client important (CI) is a proxy for auditor independence to test the economic dependence of auditors on clients [35,36]. The measurement used auditor fees, but the information is not disclosed to the public in Indonesia. Then the firm size of the client used by following the research from [36] using the following formula:

$$
\mathrm{CI}_{\mathrm{it}}=\mathrm{SIZE}_{\mathrm{it}} /\left(\Sigma \mathrm{SIZE}_{\mathrm{it}}\right)
$$

$\mathrm{CI}$ is the proportion of firm size of a particular Public Accountant Firm client (in the natural logarithm of total assets) to the total firm size of all clients of a certain Public Accountant Firm. In order to be taken into account in the Audit Quality Metric Score (AQMS), measurement of CI proxy as a measure of high audit quality, even though the Public Accountant Firm has an economic interest in the client, it still has independence if the CI ratio is in the interval $\mu-\sigma \leq C I \leq \mu+\sigma^{5}$ where $\mu$ is mean of the CI value and $\sigma$ is the standard deviation. If the value of the $\mathrm{CI}$ ratio of company $\mathrm{i}$ that is audited by a particular Public Accountant Firm meets these criteria, it will be given a number 1 , and 0 otherwise.

The AQMS variable is the sum of scores from 4 proxies which are the dimensions of competence (Accountant Public Firm size, industry specialization and audit tenure) and independence dimensions (client importance). A summary of variable measurements is presented in the table 2 below. 
Table 2. Variable measurement

\begin{tabular}{|c|c|c|c|}
\hline Variable & Dimension & Indicator & Scale of measurement \\
\hline IFRS convergence & $\begin{array}{l}\text { Standards accounting domestic to } \\
\text { IFRS convergence }\end{array}$ & $\begin{array}{l}\text { IFRS accounting standards } \\
\text { applied by the company divided } \\
\text { by the number of accounting } \\
\text { standards issued by the relevant } \\
\text { profession }\end{array}$ & Ratio \\
\hline Audit Quality & $\begin{array}{l}\text { Auditor independence and } \\
\text { competence }\end{array}$ & $\begin{array}{c}\text { Big } 4 \text { non big 4,Special } \\
\text { industry, Tenure, Client } \\
\text { Important }\end{array}$ & Ratio \\
\hline Disclosure Quality & Annual report & Disclosure Index & Ratio \\
\hline
\end{tabular}

\section{Multiple Linear Regression}

This study used multiple linear regression analysis to examine the role of the moderating variable of Audit Quality on the relationship between IFRS convergence on Dislosure Quality. Multiple regression analysis can be described in three regression equation to test hypotheses 1 and hypotheses 2 as follows:

$$
\begin{gathered}
\text { DQ }=\alpha+\beta_{1} \text { IFRS } \\
\text { DQ }=\alpha+\beta_{1} \text { IFRS }+\beta_{2} \text { AQMS } \\
\mathrm{DQ}=\alpha+\beta_{1} \text { IFRS }+\beta_{2} \text { AQMS }+\beta_{3} \text { IFRS* } \beta_{4} \mathrm{AQMS}+\beta_{5} \\
\text { ROA } \\
\mathrm{DQ}=\text { Disclosure Quality } \\
\text { IFRS }=\text { IFRS convergence } \\
\mathrm{AQMS}=\text { Audit Quality Matric Score } \\
\text { ROA }=\text { Control Variable }
\end{gathered}
$$

\section{Research Finding}

Table 3. Descriptive statistics

\begin{tabular}{|c|c|c|c|c|}
\hline Variable & Minimum & Maximum & Mean & Std. Deviation \\
\hline DQ & 32.0000 & 83.0000 & 65.267574 & 9.2572363 \\
\hline IFRS & .2857 & .9388 & .532458 & .0905172 \\
\hline AQMS & .0000 & 4.0000 & 2.263039 & .8167112 \\
\hline ROA & -5.4002 & 4.0000 & .304753 & .7046497 \\
\hline
\end{tabular}

Table 3 showed descriptive statistics and table 4 showed the results of the regression parameter test on the equation model.

Disclosure quality has a minimum value of 32 , a maximum value of 83 , an average value of 65.2676 and a standard deviation of 9.2572 . IFRS convergence has a minimum value of 0.2857 , a maximum value of 0.9388 , an average value of 0.5325 and a standard deviation of 0.0905 . Audit quality Metric Score has a minimum value of 0 maximum value 4 average value 2.2630 and standard deviation 0.8167 .

The dependent variable is Disclosure Quality which is influenced by the IFRS convergence variable and the moderating variable is Audit Quality in table 4 explained by the mathematical equation used 3 models:

The R-Squared value showed 0.033 (model 1), 0,042 (model 2) and 0,063 (model 3) which means 3,3\%, 4,2\% and 6,3\% of the dependent variation of Disclosure Quality can be explained by the independent variable in the equation, while the remaining around $90 \%$ is explained by other reasons outside the model. The IFRS convergence variable showed a significance probability $<0.05$ with a positive direction so it can be concluded that IFRS convergence has a significant positive effect on Disclosure Quality.

The interaction variable IFRS convergence and Audit Quality as moderating variables showed significance probability $<0.05$, so it can be concluded that the Disclosure Quality variable is influenced by IFRS convergence variable and the Audit Quality moderating variable, and the Audit Quality variable acts as a moderation. 
Table 4. Equation Model Regression Parameter Test Results

\begin{tabular}{|c|c|c|c|c|c|c|}
\hline \multirow{2}{*}{ Variabel } & \multicolumn{2}{|c|}{ Model 1} & \multicolumn{2}{|c|}{ Model 2} & \multicolumn{2}{|c|}{ Model 3} \\
\hline & $\beta$ Coef & Sig & $\beta$ Coef & Sig & $\beta$ Coef & Sig \\
\hline IFRS & 18.477 & $0.000^{* *}$ & 21.571 & $0.000 * *$ & 19.436 & $0.018^{* *}$ \\
\hline AQMS & & & 12.238 & $0.020^{* *}$ & 0.746 & $0.026^{* * *}$ \\
\hline ROA & & & 1.643 & $0.009^{* *}$ & 1.646 & $0.009 * *$ \\
\hline IFRS*AQMS & & & & & 0.907 & $0.023^{* *}$ \\
\hline R-Square & \multicolumn{2}{|c|}{$0,033(3,3 \%)$} & \multicolumn{2}{|c|}{$0,042(4,2 \%)$} & \multicolumn{2}{|c|}{$0,063(6,3 \%)$} \\
\hline
\end{tabular}

Source: processed secondary data (2019)

Description: Dependent variable Disclosure Quality

**significance at $5 \%$ level *significance at $10 \%$ level

\section{Hypothesis Test}

Based on table 4 , the probability value of IFRS convergence is 0.018 with a positive coefficient direction, and the value is significant at the 5\% level, which means that IFRS convergence has a positive and significant effect on Disclosure Quality. The value showed that hypothesis 1 is ACCEPTED.

Based on table 4, the probability value of the interaction between IFRS and Audit Quality is 0.023 with a positive coefficient direction; the value is significant at the 5\% level, which means that Audit Quality moderates the relationship between IFRS convergence and Disclosure Quality. The value showed that hypothesis 2 is ACCEPTED

\section{Discussion}

IFRS convergence in agency theory concept is placed in a reporting perspective. IFRS convergence acts as a control function carried out by stakeholders and interested parties in financial reporting to monitor management work. The implementation of IFRS in financial statements shows an increase in the amount of business information [6]. Mensah [7] said that the quantity and quality of the information will improve the quality of financial reports and will be very useful for decision making. Information asymmetry is expected to be reduced by the amount and quality of information disclosed in the financial statements.

The implementation of IFRS affected the quality of disclosure. Quality disclosure will provide explanations and important information from the figures presented in the financial statements. The quality of disclosure plays a role in improving the quality of the financial statements presented by the company and useful for decision maker. Information obtained from the company's financial statements depends on the level of disclosure of the relevant financial statements.
Audit plays an important role in monitoring contracts and reducing information risks. So the audit role will oversee the financial reporting process carried out by the company and it can produce quality financial reports. Audit quality plays a role in strengthening the positive relationship between IFRS convergence and disclosure quality. So that the external audit provides assurance the financial statements presented have met the standards for preparing financial statements and are presented fairly without material errors.

\section{Conclusions}

The research proved the implementation of IFRS convergence in Indonesia has proven to affect disclosure quality. This study supports the results of previous research from [6] which proved that the effect of IFRS convergence on disclosure helps improve the comparability of information presented in financial statements. According to [11] the quality of the disclosures presented is also related to earnings information in financial statements so as to assist investors in making decisions.

The audit quality variable acts as a moderating variable and it can strengthen the positive effect of IFRS convergence on disclosure quality. IFRS convergence applied requires the role of external audit to provide assurance or assurance that the financial statements presented have complied with the standards for preparing financial statements and are fairly presented without material errors. Veronica [14] and Mujtahidin [15] said audit quality will strengthen the position of financial statements and carry out the monitoring function as part of the company's good corporate governance. Moderating variable is expected to strengthen the relationship between the effects of IFRS convergence on increasing corporate disclosure. Using the concept of agency theory which says that management cannot be trusted and supervision is needed, then the management can be controlled by using audit as a monitoring function to reduce agency costs. 


\section{Acknowledgments}

Our gratitude goes to Lembaga Penelitian dan Pengabdian Masyarakat Universitas Muhammadiyah Semarang for the support and assistance provided for the improvement of scientific publications.

\section{REFERENCES}

[1] Yoon Sora, "Accounting Quality and International Accounting Convergence," 2007.

[2] C. Armstrong, M. E. Barth, A. D. Jagolinzer, and E. J. Riedl, "Market Reaction to Events Surrounding the Adoption of IFRS in Europe Market Reaction to Events Surrounding the Adoption of IFRS in Europe," Account. Rev., vol. 85, no. 1, pp. 31-61, 2010.

[3] M. Petreski, "The Impact of International Accounting Standards on Firms Marjan Petreski,” pp. 4-5, 2005.

[4] J. L. Blouin, C. A. Gleason, L. F. Mills, and S. A. Sikes, "Pre-empting disclosure? Firms' decisions prior to FIN No. 48," Account. Rev., vol. 85, no. 3, pp. 791-815, 2010.

[5] M. A. Borkowski, S.C., Gaffney, "FIN 48, uncertainty and transfer pricing: (Im)Perfect together?," J. Int. Accounting, Audit. Tax., vol. 21, no. 1, pp. 32-51, 2012.

[6] G. H. Mardini, L. Crawford, D. M. Power, G. H. Mardini, L. Crawford, and D. M. Power, "The impact of IFRS 8 on disclosure practices of Jordanian listed companies," $J$. Account. Emerg. Econ., vol. 2, no. 1, pp. 67-90, 2014.

[7] B. K. Agyei-Mensah, "Adoption of International Financial Reporting Standards (IFRS) in Ghana and the Quality of Financial Statement Disclosures," Int. J. Account. Financ. Report., vol. 3, no. 2, p. 269, 2014.

[8] H. de La Bruslerie and H. Gabteni, "Voluntary disclosure of financial information by French firms: Does the introduction of IFRS matter?," Adv. Account., vol. 30, no. 2, pp. 367-380, 2014

[9] O. Hope, "Firm-level Disclosures and the Relative Roles of Culture and Legal Origin," J. Int. Financ. Manag. Account., vol. 14, no. 3, pp. 218-248, 2003.

[10] N. H. Akman, "The Effect of IFRS Adoption on Financial Disclosure : Does Culture Still Play A Role?," Am. Int. J. Contemp. Res., vol. 1, no. 1, pp. 6-17, 2011.

[11] D. Adhariani, "Tingkat Keluasan Pengungkapan Sukarela Dalam Laporan Keuangan Dan Hubungannya Dengan Current Earnings Response Coefficient (ERC)," J. Akunt. dan Keuang. Indones., vol. 2, no. 1, pp. 24-57, 2005.

[12] W. A. Wallace and W. Kreutzfeldt, "The Relation of Inherent and Control Risks to Audit Adjustments," $J$. Accounting, Audit. Financ., pp. 459-481, 1995.

[13] A. Marra, P. Mazzola, and A. Prencipe, "Board monitoring and earnings management pre- and post-IFRS," Int. J. Account., vol. 46, no. 2, pp. 205-230, 2011.
[14] S. Veronica and Y. S. Bachtiar, "Corporate Governance, Information Asymmetry and Earnings Management," $J$. Akunt. dan Keuang. Indones., vol. 2, no. 1, pp. 77-106, 2005.

[15] M. Mujtahidin, Herawati, "Pengaruh Implementasi IFRS, Corporate Governance, Profitabilitas dan Leverage Terhadap Real dan Accrual Based Earning Management," in Seminar Nasional Cendikiawan, 2016, no. 1, pp. 1-14.

[16] N. Mutmainnah and R. Wardhani, "Analisis Dampak Kualitas Komite Audit Terhadap Kualitas Laporan Keuangan Perusahaan Dengan Kualitas Audit Sebagai Variabel Moderasi," J. Akunt. dan Keuang. Indones., vol. 10, no. 2, pp. 147-170, 2013.

[17] A. Istiqomah and D. Adhariani, "Pengaruh Manajemen Laba terhadap Stock Return dengan Kualitas Audit dan Efektivitas Komite Audit sebagai Variabel Moderasi," J. Akunt. dan Keuang., vol. 19, no. 1, pp. 1-12, 2017.

[18] G. P. Sari and S. L. Indarto, "Pengaruh Pergantian Auditor, Tenur Audit, dan Frekuensi Rapat Komite Audit Terhadap Kualitas Laporan Keuangan dengan Kualitas Audit Sebagai Variabel Moderating," J. Akunt. Bisnis, vol. 16, no. 2, pp. 230-245, 2018

[19] M. C. Jensen and W. H. Meckling, "Theory of the Firm: Managerial Behavior, Agency Costs and Ownership Structure," J. financ. econ., vol. 3, no. 4, pp. 305-360, 1976.

[20] G. J. Lobo, J. Zhou, G. J. Loboa, and J. Zhoub, “Disclosure quality and earnings management Disclosure quality and earnings management," Asia-Pacific J. Account. Econ., vol. 8, no. October, pp. 1-20, 2015.

[21] M. Pour, S.H., Arabi, "The Effect of Voluntary Disclosure on the Relationship between Accruals Quality and Information Asymmetry," J. Life Sci. Biomed., vol. 5, no. 1, pp. 15-20, 2015.

[22] Y. Sun, "Do MD\&A disclosures help users interpret disproportionate inventory increases?," Account. Rev., vol. 85, no. 4, pp. 1411-1440, 2010.

[23] M. El Diri, Introduction to Earnings Management. 2018.

[24] T. Hastuti, "Pengaruh Penerapan Standar Akuntansi Berbasis IFRS dan Siklus Hidup Perusahaan Terhadap Manajemen Laba Dengan Pengendalian Internal Sebagai Variabel Moderasi," Universitas Diponegoro Semarang, 2017.

[25] Y. Ding, "Differences between domestic accounting standards and IAS: Measurement, determinants and implications," J. Account. Public Policy, vol. 26, pp. 1-38, 2007.

[26] Muhtarudin, “" Analisis Pengaruh Besarnya Tingkat Leverage dan Ukuran Perusahaan Terhadap Tingkat Pengungkapan Informasi Laporan Tahunan ( Disclosure Level Annual Report)," J. Manajerial, vol. 10, no. 20, pp. 67-81, 2012.

[27] Irma, "Analisis pengaruh tingkat pengungkapan terhadap likuiditas saham," J. Organ. dan Manaj., vol. 9, no. 1, pp. 54-72, 2013.

[28] A. Herusetya, "Analisis Kualitas Audit Terhadap Manajemen Laba Akuntansi : Studi Pendekatan Composite 
Measure Versus Conventional Measure," J. Akunt. dan Keuang. Indones., vol. 9, pp. 117-135, 2012.

[29] A. O. Okolie, "Audit Quality and Earnings Response Coefficients of Quoted Companies in Nigeria," J. Appl. Financ. Bank., vol. 4, no. 2, pp. 139-161, 2014.

[30] A. Kouaib and A. Jarboui, "External audit quality and ownership structure: Interaction and impact on earnings management of industrial and commercial tunisian sectors," J. Econ. Financ. Adm. Sci., vol. 19, no. 37, pp. 78-89, 2014.

[31] S. Balsam, J. Krishnan, and J. S. Yang, "Auditor industry specialization and earnings quality," Auditing, vol. 22, no. 2, pp. 71-97, 2003.

[32] M. Hegazy and R. Hamdy, "The Effect of Audit Firm Specialization on Earnings Management and Quality of Audit Work," J. Account. Financ., vol. 15, no. 4, pp. 143 $164,2015$.

[33] F. A. Gul, S. Y. K. Fung, and B. Jaggi, "Earnings quality:
Some evidence on the role of auditor tenure and auditors industry expertise," J. Account. Econ., vol. 47, no. 3, pp. 265-287, 2009.

[34] B. González-Díaz, R. García-Fernández, and A. López-Díaz, "Auditor tenure and audit quality in Spanish state-owned foundations," Rev. Contab., vol. 18, no. 2, pp. 115-126, 2015.

[35] C.O. Ikharo, "The Impact of Auditor's Tenure on Quality Audit Report," Res. J. Financ. Account., vol. 6, no. 1, pp. 91-97, 2015.

[36] S. Chen, S. Y. J. Sun, and D. Wu, "Client importance, institutional improvements, and audit quality in China: An office and individual auditor level analysis," Account. Rev., vol. 85, no. 1, pp. 127-158, 2010.

[37] C. Ettredge, M., Fuerherm, E.E., Li, "Fee pressure and audit quality," Accounting, Organ. Soc., vol. 39, pp. 247-263, 2014. 